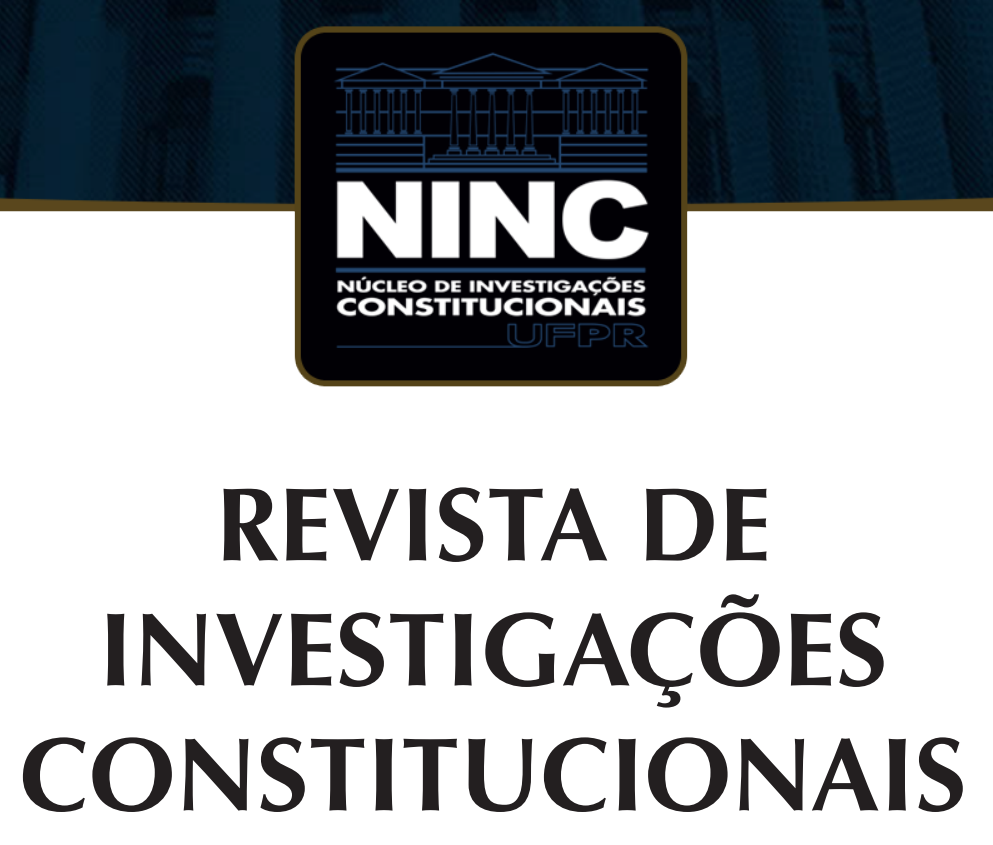

JOURNAL OF CONSTITUTIONAL RESEARCH

vol. 8 | n. 2 | maio/agosto 2021 | ISSN 2359-5639 | Periodicidade quadrimestral Curitiba | Núcleo de Investigações Constitucionais da UFPR | www.ninc.com.br 


\title{
O STF e os parâmetros para o controle dos atos do poder legislativo: limitações do argumento das questões interna corporis
}

\author{
Brazilian Supreme Court and the parameters for the \\ control of the acts of the legislative power: limitations \\ of the argument of corporis internal issues
}

\author{
ANA PAULA DE BARCELLOS 1 ,* \\ ' Universidade do Estado do Rio de Janeiro (Rio de Janeiro, Rio de Janeiro, Brasil) \\ anapauladebarcellos@gmail.com \\ https://orcid.org/0000-0003-2784-3406 \\ Recebido/Received: 21.04.2021/ April 21 2021 \\ Aprovado/Approved: 28.07.2021 / July $28^{\text {th }}, 2021$
}

Resumo

O controle judicial de atos praticados pelo Poder Legislativo é um tema especialmente sensível das relações entre a Constituição, jurisdição constitucional e democracia. O STF invoca com frequência a figura das questões "interna corporis" para concluir pela eventual impossibilidade de revisão judicial de atos do Legislativo. O objetivo deste texto é contribuir para identificar o que são - e o que não são - questões "interna corporis" por meio do exame da seguinte pergunta. A qualidade de "interna corporis" de uma questão decorreria de ela envolver a interpretação de normas regimentais das Casas Legislativas, como sugerido pelo Ministro Relator no Tema 1.120 de Repercussão Geral? A jurisprudência do STF examinada revela que

\section{Abstract}

Judicial review of Legislative acts is a sensitive issue in the intersection between Constitution, judicial review, and Democracy. The Brazilian Supreme Court (STF) often resources to the "interna corporis" question when deciding it cannot review a Legislative act. The purpose of this paper is to help identify what "interna corporis" questions are and are not via the answer to the following question. Are "interna corporis" questions those involving the construe of Legislative internal rules, as suggested by the Reporting Justice in General Repercussion Theme 1,120? The exam of the STF case law answers no to this question. Despite the frequent repetition of the idea conveyed by the Reporting Justice in Theme 1,120 , in many cases, the Brazilian Supreme Court decided

Como citar esse artigo/How to cite this article: BARCELLOS, Ana Paula de. O STF e os parâmetros para o controle dos atos do poder legislativo: limitações do argumento das questões interna corporis. Revista de Investigações Constitucionais, Curitiba, vol. 8, n. 2, p. 435-456, maio/ago. 2021. DOI: 10.5380/rinc.v8i2.80693.

" Professora Titular de Direito Constitucional da Faculdade de Direito da Universidade do Estado do Rio de Janeiro (Rio de Janeiro-RJ, Brasil). Doutora e Mestre em Direito pela Universidade do Estado do Rio de Janeiro. Pós-doutorado pela Universidade de Harvard (2012/2013).E-mail: anapauladebarcellos@gmail.com. 
a resposta a essa pergunta é negativa. A despeito de afirmações genéricas contidas em decisões reproduzindo essa assertiva, em diversos casos o STF decidiu controlar atos do Legislativo a despeito de a hipótese envolver a interpretação de normas regimentais. A jurisprudência examinada sugere que o critério utilizado pelo STF para definir sua intervenção é a presença de elementos constitucionais que a Corte entendeu relevantes e que deviam ser protegidos, independentemente da necessidade de interpretação de normas regimentais.

Palavras-chave: Poder Legislativo; questões "interna corporis"; controle judicial; jurisprudência; STF. to review Legislative acts despite the need to construe Legislative internal rules. The Court did so to protect Constitutional elements identified as relevant.

Keywords: Legislative branch; judicial review; "interna corporis" questions; Brazilian Supreme Court case law.

\section{SUMÁRIO}

1. Introdução; 2. Interpretação das normas regimentais: é esse o critério que o STF utilizada para definir questões interna corporis? 2.1. O tema de Repercussão Geral 1.120 e as diferentes atividades desenvolvidas pelo Poder Legislativo; 2.2. Jurisprudência do STF: a interpretação de normas regimentais não é um critério que corresponda ao entendimento consolidado da Corte na definição das questões "interna corporis"; 3. Com base em quais fundamentos afinal o STF controla atos do Poder Legislativo? Uma tentativa preliminar de sistematização e crítica; 4. Conclusão; 5. Referências.

\section{INTRODUÇÃO}

Há muitas décadas o STF utiliza a cláusula das questões "interna corporis" quando entende que não lhe cabe controlar atos do Legislativo. Mas o que são afinal questões "interna corporis"? Não há resposta simples para essa pergunta e a pouca consistência da jurisprudência em delinear o sentido da expressão levou pesquisadores à conclusão de que a Corte usa o argumento estrategicamente'

No âmbito do Tema 1.120 de Repercussão Geral, o Ministro Dias Toffoli, Relator do recurso extraordinário vinculado, propôs que a seguinte tese fosse fixada a fim de refletir a jurisprudência consolidada da Corte no particular: "Em respeito ao princípio da separação dos poderes, previsto no art. $2^{\circ}$ da Constituição Federal, é defeso ao Poder Judiciário exercer o controle jurisdicional em relação à interpretação de normas regimentais das Casas Legislativas, por se tratar de matéria interna corporis.". Embora os demais Ministros tenham concordado, de forma unânime, que a questão era constitucional e deveria ser apreciada em sede de repercussão geral, rejeitaram a tese sugerida pelo Relator ${ }^{2}$. Em algum momento a questão será apreciada pelo Plenário.

\footnotetext{
1 Sobre o tema, v. LIMA, Flávia Danielle Santiago; GOMES NETO, José Mário Wanderley. Autocontenção à brasileira? Uma taxonomia dos argumentos jurídicos (e estratégias políticas?) explicativo(a)s do comportamento do STF nas relações com os poderes majoritários. Revista de Investigações Constitucionais, Curitiba, vol. 5, n. 1, p. 221-247, jan./abr. 2018.
}

2 A deliberação foi feita via plenário virtual e encerrou-se em 17 dez. 2020. 
O presente estudo quer apurar se a "interpretação das normas regimentais das Casas Legislativas", como pareceu entender o Ministro Relator do Tema 1.120 - RG, é realmente o critério utilizado pelo STF para identificar questões "interna corporis", e assim limitar sua atuação no controle dos atos do Legislativo. O exame da jurisprudência do próprio STF é o método principal para alcançar esses objetivos. O texto não faz um exame exaustivo da jurisprudência, porque tal esforço não seria necessário do ponto de vista metodológico para os objetivos aqui pretendidos. Como se verá, a resposta a tal pergunta é negativa: a Corte não utiliza de forma consistente esse critério, apesar de enunciá-lo com frequência ${ }^{3}$, controlando atos do Poder Legislativo mesmo diante da presença de normas regimentais a serem interpretadas, invocando para tanto o impacto da questão sobre elementos constitucionais considerados relevantes em cada caso.

Identificar que parâmetros o STF adota, ou não, para definir os limites e possibilidades do controle judicial dos atos do Poder Legislativo é um tema importante por três razões que se interligam. Em primeiro lugar, a atuação do Judiciário controlando a atividade do Poder Legislativo tensiona a separação de poderes. Assim, os critérios que orientam essa atuação devem ser, em primeiro lugar, claros, comunicando um conteúdo que possa ser compreendido pelo restante da sociedade; em segundo lugar, consistentes, isto é: capazes de justificar-se lógica e juridicamente à luz do sistema constitucional; e, por fim, previsíveis, a saber: específicos o suficiente para serem reproduzíveis e, portanto, gerar previsibilidade.

Como se verá, a cláusula das "questões interna corporis" utilizada pelo STF sem maiores desenvolvimentos acerca do seu real conteúdo não atende essas exigências, sobretudo em casos em que a questão seja politicamente relevante e parlamentares ou partidos, frequentemente de oposição, solicitam à Corte que intervenha no que tenha ocorrido no âmbito da Casa Legislativa. Naturalmente que critérios, mesmo específicos, jamais serão capazes de dar conta de toda a realidade ou antecipar todos os questionamentos que possam vir a surgir, mas a perfeição inatingível não deve inviabilizar o avanço possível.

Em segundo lugar, a adoção pelo STF de critérios mais claros, consistentes e previsíveis que orientem sua atuação no controle de atos do Poder Legislativo é fundamental para orientar as decisões monocráticas dos próprios Ministros da Corte e do restante do Poder Judiciário. Para além do Congresso Nacional, cada Estado, cada Município e o Distrito Federal têm seus próprios Legislativos e cabe ao Judiciário local apreciar originariamente questionamentos acerca de seus atos. Se a questão decorre

3 Para diversos exemplos, v. SALGADO, Eneida Desiree; ARAÚJO, Eduardo Borges Espínola. Controle judicial do processo legislativo. Do minimalismo à garantia do devido procedimento legislativo. RIL, Brasília, a. 56, n. 224, p. 79-104, out./dez. 2019. 
da separação de poderes, salvo normas locais que criem previsões específicas eventualmente aplicáveis, parece natural que os critérios fixados pelo STF deverão ser igualmente empregados pelos demais órgãos do Poder Judiciário e igualmente pelos Ministros da própria Corte ao produzirem decisões monocráticas ${ }^{4}$.

Por fim, e em terceiro lugar, assumindo que o controle judicial dos atos do Legislativo se justifica a fim de garantir a observância de elementos constitucionais considerados da maior relevância, será potencialmente melhor para promovê-los que os Legislativos, de todas as esferas federativas, tenham clareza acerca de quais são esses elementos e possam prever o comportamento do Judiciário no caso de questionamentos. Existe já alguma evidência acerca do Congresso Nacional no sentido de que o Legislativo tende a adequar seu comportamento a decisões claras e previsíveis do STF para evitar a eventual invalidação de seus futuros atos. É o que tem acontecido, por exemplo, no caso da exigência de comissões mistas para exame das medidas provisórias ${ }^{5}$ e da vedação a emendas que constituam "contrabandos legislativos" também no âmbito de MPs ${ }^{6}$. É razoável imaginar, portanto, que decisões claras, consistentes e previsíveis do STF no particular terão o potencial de prevenir futuras violações aos entendimentos já firmados pela Corte na rotina das atividades dos Poderes Legislativos dos vários níveis federativos.

\footnotetext{
4 V. Sobre a importância das decisões monocráticas na dinâmica do STF, v. PEREIRA, Thomas, ALMEIDA, GuiIherme da Franca Couto Fernandes de, e ARGUELHES, Diego Werneck. VIII Relatório Supremo em Números: Quem decide no Supremo. Rio de Janeiro: Editora FGV Rio, 2020.

5 V. BEDRITICHUK, R. R. Medida Provisória, uma moeda inflacionada: A inclusão das comissões no rito de tramitação das medidas provisórias e o aumento dos custos de aprovação. Brasília, 2015. 59 f. Monografia (especialização). Disponível em: <https://www2.senado.leg.br/bdsf/bitstream/handle/id/516859/TCC_Rodrigo\%20Ribeiro\%20Bedritichuk.pdf?sequence=1\&isAllowed $=y>$.

6 V. LAAN, Cesar Rodrigues Van Der. Um panorama recente da apresentação de emendas sem pertinência temática a medidas provisórias pós-ADI 5.127. Brasília: Núcleo de Estudos e Pesquisas, CONLEG/Senado, Fevereiro/2018 (Texto para Discussão no 244). Disponível em <https://www12.senado.leg.br/publicacoes/estudos-legislativos/tipos-de-estudos/textos-para-discussao/td244>:"Resumo. Houve mudança significativa no comportamento dos parlamentares após a decisão do STF na ADI n 5.127/DF, quando considerou ser incompatível com a Constituição a apresentação de emendas parlamentares sem relação de pertinência temática com medida provisória (MP) submetida a sua apreciação? O presente trabalho faz uma análise no âmbito do Direito empírico para avaliar os efeitos concretos da decisão do STF de outubro de 2015, objetivando identificar a mudança esperada sobre o nível de pertinência temática das emendas parlamentares oferecidas a MPs em relação ao padrão anterior, objeto de questionamento judicial. Mapeando as MPs e emendas parlamentares apresentadas nas comissões mistas entre jan./14 e out./16, identificou-se uma redução na quantidade geral de emendas parlamentares apresentadas, simultânea à redução no percentual de "jabutis". Como principal constatação, observa-se menor quantidade de emendas dispondo sobre matérias "totalmente" estranhas, mas também a permanência de oferecimento de emendas consideradas conexas com a matéria veiculada originalmente na MP."
} 


\section{INTERPRETAÇÃO DAS NORMAS REGIMENTAIS: É ESSE O CRITÉ- RIO QUE O STF UTILIZADA PARA DEFINIR QUESTÕES INTERNA CORPORIS?}

\subsection{O tema de Repercussão Geral 1.120 e as diferentes atividades desenvolvidas pelo Poder Legislativo}

O Ministro Dias Toffoli no Tema 1.120 de Repercussão Geral entendeu, nos termos de sua proposta, que a jurisprudência consolidada da Corte poderia ser expressa por meio do seguinte enunciado: "Em respeito ao princípio da separação dos poderes, previsto no art. $2^{\circ}$ da Constituição Federal, é defeso ao Poder Judiciário exercer o controle jurisdicional em relação à interpretação de normas regimentais das Casas Legislativas, por se tratar de matéria interna corporis.". Os demais Ministros, embora concordando com a necessidade de o STF examinar e decidir o tema, ou bem não concordaram que tal enunciado refletia a jurisprudência da Corte, ou bem entenderam que a Corte não tem uma jurisprudência consolidada na matéria ou que, se o tem, ela deveria ser alterada. Os votos lançados no Plenário virtual não precisam ser fundamentados - e efetivamente não foram - de modo que não é possível saber as razões pelas quais cada Ministro rejeitou a tese proposta pelo Relator.

A tese foi proposta pelo Ministro Relator em termos gerais com a pretensão aparente de solucionar a questão do controle jurisdicional de atos do Poder Legislativo de forma ampla. O recurso extraordinário vinculado, porém, trata de situação bastante particular no âmbito do processo legislativo que resultou na Lei 13.654/18, e que, de fato, já foi diversas vezes examinada pelo STF. O acórdão objeto do recurso extraordinário dirigido ao STF entendeu que o art. $4^{\circ}$ da Lei 13.654/18 seria formalmente inconstitucional pois houve um erro na publicação no Diário Oficial do Senado Federal após decisão da Comissão de Constituição, Justiça e Cidadania do Senado que incluiu o dispositivo no projeto de lei. $\mathrm{O}$ acórdão recorrido entendeu que tal erro corresponderia a um vício insanável do processo legislativo, e teria prejudicado a ciência do restante dos Senadores acerca do que havia sido decidido pela CCJC, bem como sua possibilidade de apresentar recurso contra a decisão terminativa da Comissão para o Plenário.

De forma mais específica, o que se passou foi o seguinte. A CCJC do Senado alterou o projeto de lei em caráter terminativo para incluir artigo prevendo a revogação do inciso I do $\S 2^{\circ}$ do art. 157 do Código Penal, que previa aumento de pena para o crime de roubo se a violência ou ameaça fosse "exercida com emprego de arma". Entretanto, o texto publicado no Diário Oficial do Senado Federal não incluiu esse artigo aprovado no âmbito da CCJC. Não houve recurso da decisão da Comissão para o Plenário do Senado. Antes da remessa do PL à Câmara dos Deputados, verificou-se o erro que foi 
corrigido pela CORELE - Coordenação de Redação Legislativa. A Câmara manteve a previsão de revogação do inciso I do $\S 2^{\circ}$ do art. 157 do Código Penal aprovada pela CCJC do Senado, mas aprovou um substitutivo ao PL. Esse substitutivo - que continha em seu art. $4^{\circ}$ a revogação do inciso I do $\S 2^{\circ}$ do art. 157 do Código Penal - foi novamente submetido ao Senado Federal, aprovado e sancionado dando origem à Lei 13.654/18.

Em seu voto, o Ministro Dias Toffoli lista várias decisões, de diferentes Ministros, no sentido de não visualizar inconstitucionalidade formal na hipótese, sob o argumento de para isso seria necessário interpretar disposições regimentais, o que restaria vedado pois se trataria de questão "interna corporis". Embora tenha sido selecionado para fins de repercussão geral, o caso parece bastante particular e é sintomático que o tema tenha chegado ao STF no contexto de processos penais nos quais a norma está sendo aplicada, e não por meio de demandas ajuizadas por parlamentares derrotados na disputa político-parlamentar. Seja como for, a tese proposta pelo Ministro Relator, como se viu, não faz qualquer referência específica às circunstâncias do caso que deu origem ao recurso e, a rigor, sequer limita sua aplicação ao universo do processo legislativo.

Pois bem. A pergunta então a ser examinada pode ser enunciada da seguinte forma. Seria consistente afirmar, como sugeriu o Ministro Dias Toffoli nos termos acima descritos, que o critério adotado pela jurisprudência do STF acerca da possibilidade ou não de controle judicial dos atos do Poder Legislativo é a circunstância de os casos envolverem ou não interpretação de normas regimentais? Ou ao menos esse seria o caso no contexto do processo legislativo (que é do que trata afinal o recurso extraordinário vinculado)? E resposta é negativa.

Sem pretender propor uma teoria geral dos atos do Poder Legislativo, é possível visualizar no sistema organizado pela Constituição de 1988 ao menos 3 (três) outras atividades especialmente relevantes levadas a cabo pelo Legislativo para além da elaboração normativa. Cabe às Casas (i) sua organização interna e de seus serviços; (ii) os Legislativos desenvolvem importantes atividades de fiscalização, que podem incluir a restrição a direitos de terceiros; e (iii) há ainda as atividades decorrentes das competências sancionatórias, que podem atingir tanto os próprios parlamentares quanto terceiros. Como se verá, ao examinar atos praticados pelo Legislativo no âmbito das atividades (i), (ii) e (iii), o tema da interpretação de normas regimentais sequer é especialmente relevante na jurisprudência do STF. E mesmo em relação ao processo legislativo (iv), também não é correta a afirmação de que o critério usado pela Corte para decidir o que seria ou não questão "interna corporis" é a necessidade de interpretação de normas regimentais.

A demonstração da afirmação acima não exige, do ponto de vista metodológico, uma pesquisa exaustiva da jurisprudência da Corte. Basta verificar que há diversas decisões, que sequer são sinalizadas como casos excepcionais, nas quais o STF não 
utiliza o critério da interpretação das normas regimentais para balizar sua atividade de controle de atos do Poder Legislativo. É disso que trata o próximo tópico.

\subsection{Jurisprudência do STF: a interpretação de normas regimentais não é um critério que corresponda ao entendimento consolida- do da Corte na definição das questões "interna corporis"}

Inicie-se pelo tema da organização interna do próprio legislativo. O STF tem uma tradicional jurisprudência - o HC 129.129, Rel. Min. Carmen Lúcia, DJe 25.11.2019, é apenas um exemplo - no sentido de invalidar atos de Presidentes das Casas Legislativas que tornem fechadas as sessões de modo a impedir o ingresso do público. No HC 129.129, os impetrantes pretendiam a invalidade de ato do Presidente da Câmara dos Deputados que havia decidido que a sessão de votação da PEC 171/93, que tratava da redução da maioridade penal, não seria aberta ao público, de modo que lhes fosse garantida a entrada nas galerias do plenário onde a sessão ocorreria. A ordem foi concedida em parte para assegurar os impetrantes tal direito, sem prejuízo da devida observância das medidas de policiamento da Casa.

Ao examinar o argumento da autoridade coatora de que se trataria de norma interna e, portanto, de questão "interna corporis", a Ministra Relatora afirmou apenas que "o Supremo Tribunal Federal firmou entendimento de ser viável o controle jurisdicional para salvaguardar os preceitos constitucionais", transcrevendo na sequência trecho do MS 24.849, no qual a Corte reconheceu o direito da minoria parlamentar de ver instaurada comissão parlamentar de inquérito, tema sobre o que se tratará adiante.

Embora o ato discutido no habeas corpus fosse de fato um ato interno relacionado com a organização e funcionamento das sessões da Casa, e inexista qualquer norma constitucional específica dispondo sobre a necessidade de as sessões das casas legislativas serem abertas ao público, o entendimento da Corte foi o de que a proibição prévia do acesso do público afetava elementos relevantes da Constituição: não apenas o direito de ir e vir, como também a cidadania e a participação democrática. O STF, portanto, considerou possível rever e invalidar ato interno da Casa Legislativa - do seu Presidente - e afastou o argumento de que se trataria de questão "interna corporis" pelo impacto do ato em questão sobre elementos constitucionais, ainda que não se tratasse de norma constitucional específica que estivesse sendo violada.

Talvez a jurisprudência mais conhecida do STF sobre o controle de atos legislativos seja aquela que se dirige ao exercício de suas competências de fiscalização, em particular no que diz respeito às comissões parlamentares de inquérito. Na realidade, há dois corpos distintos de decisões relevantes nesse tema. O primeiro envolve o entendimento, citado inclusive pela Ministra Carmen Lúcia no caso referido acima, de que a minoria parlamentar tem o direito de ver constituída a comissão parlamentar de 
inquérito a despeito da omissão dos partidos do bloco majoritário em indicar membros para referida comissão. Para garantir tal direito o STF não apenas interpretou normas regimentais, como determinou ao Presidente da Casa Legislativa a indicação compulsória dos membros para a composição da CPI tendo em conta a interpretação analógica de normas regimentais que preveem tal solução para outras hipóteses.

Esse tema foi enfrentado pelo STF em vários mandados de segurança (e.g., MS 24.831, MS 24.847, MS 24.849) com fundamentação similar: aqui se vai utilizar como paradigma o MS 24.831. A hipótese envolvia requerimento de instauração de CPI para investigação de casas de bingo, jogos de azar e lavagem de dinheiro, subscrita por mais de um terço dos Senadores, como exigido pela Constituição (CF/88, art. 58, § 3). O Presidente do Senado solicitou aos líderes partidários a indicação dos Senadores que integrariam a CPI, a fim de garantir a proporcionalidade na composição das comissões legislativas prevista constitucionalmente (CF/88, art. 58, § 1º). Os líderes dos partidos majoritários, porém, permaneceram inertes, inviabilizando na prática a criação da CPI. O Senador Arthur Virgílio solicitou ao Presidente do Senado que suprisse tal omissão, mas ele se negou sob o fundamento de que as normas regimentais reservam tal poder aos líderes dos partidos. Da decisão do Presidente houve recurso para a Comissão de Constituição, Justiça e Cidadania do Senado, desprovido.

Diante do impasse no Senado, um grupo de Senadores impetrou então o MS 24.831 perante o STF, Relator o Ministro Celso de Mello, que veio a ser julgado em 22.06.2005. Por maioria a Corte reconheceu o direito da minoria parlamentar à efetiva criação da CPI e expediu uma ordem ao Presidente do Senado nos seguintes termos: “Devendo, o Senhor Presidente do Senado, mediante aplicação analógica do art. $28, \S 1^{\circ}$ do Regimento Interno da Câmara dos Deputados, c/c o art. 85, caput, do Regimento Interno do Senado Federal, proceder, ele próprio, à designação dos nomes faltantes dos Senadores que irão compor esse órgão de investigação legislativas, observado, ainda, o disposto no $\S 1^{\circ}$ do art. 58 da Constituição da República."

A autoridade impetrada pretendeu impedir o conhecimento do writ sob o argumento de que o tema envolvia questão "interna corporis" e a interpretação de normas regimentais. Ao examinar tal argumento, porém, o STF esclareceu que é legítima a intervenção judicial na esfera orgânica dos Poderes Legislativos uma vez que eles "ultrapassem os limites delineados pela Constituição ou exerçam suas atribuições institucionais com ofensa a direitos públicos subjetivos impregnados de qualificação constitucional e titularizados, ou não, por membros do Congresso Nacional." ${ }^{\text {. No }}$ Naso, o direito da minoria de fiscalizar o exercício do poder - o direito de fazer oposição - por meio da criação de

7 BRASIL. Supremo Tribunal Federal. Mandado de Segurança n 24.831, Rel. Min. Celso de Mello, publicado em 04 ago. 2006. 
CPIs foi caracterizado como um direito público subjetivo de estatura constitucional, cujo exercício a manobra levada a cabo pelos líderes da maioria tentava inviabilizar.

O STF desenvolveu ainda um segundo corpo de decisões relacionado com as comissões parlamentares de inquérito, agora voltado a estabelecer limites aos atos praticados por essas comissões visando a proteger direitos constitucionais de terceiros. Assim, o STF reconheceu às pessoas convocadas para depor perante CPIs o direito ao silêncio como garantia contra a não-autoincriminação, independente do conteúdo de normas regimentais ${ }^{8}$. O STF exige igualmente que as deliberações que pretendam impor medidas restritivas de direitos sejam fundamentadas ${ }^{9}$ e decididas pelo colegiado ${ }^{10}$, além de ter decidido que a competências "próprias das autoridades judiciais" de que trata a Constituição não incluem providências submetidas a reserva de jurisdição ${ }^{11}$.

$\mathrm{Na}$ construção dessa jurisprudência, embora normas internas - regimentais ou editadas pelas próprias Comissões - tenham sido interpretadas pela Corte e o argumento da inviabilidade de controle judicial suscitado, ele não foi considerado um ponto relevante. O Tribunal entendeu que os atos do Legislativo, no caso das CPIs, afetavam direitos constitucionais de terceiros de modo que o controle era possível, sem se

8 BRASIL. Supremo Tribunal Federal., Habeas Corpus no 100.200, Rel. Min. Joaquim Barbosa, publicado em 27 ago. 2010: "É jurisprudência pacífica desta Corte a possibilidade de o investigado, convocado para depor perante $\mathrm{CPI}$, permanecer em silêncio, evitando-se a autoincriminação, além de ter assegurado o direito de ser assistido por advogado e de comunicar-se com este durante a sua inquirição. (...) Considerando a qualidade de investigado convocado por CPI para prestar depoimento, é imperiosa a dispensa do compromisso legal inerente às testemunhas. Direitos e garantias inerentes ao privilégio contra a autoincriminação podem ser previamente assegurados para exercício em eventuais reconvocações.".

9 BRASIL. Supremo Tribunal Federal. Mandado de Segurança no 33.663, Rel. Min. Celso de Mello, publicado em 18 ago.2015: "Deliberação da CPI/Petrobras que, embora não abrangente do domicílio dos impetrantes, ressentir-se-ia da falta da necessária fundamentação substancial. Ausência de indicação, na espécie, de causa provável e de fatos concretos que, se presentes, autorizariam a medida excepcional da busca e apreensão, mesmo a de caráter não domiciliar."

10 BRASIL. Supremo Tribunal Federal. Mandado de Segurança no 24.817, Rel. Min. Celso de Mello, publicado em 6 nov. 2009: "O princípio da colegialidade traduz diretriz de fundamental importância na regência das deliberações tomadas por qualquer CPI, notadamente quando esta, no desempenho de sua competência investigatória, ordena a adoção de medidas restritivas de direitos, como aquelas que importam na revelação (disclosure) das operações financeiras ativas e passivas de qualquer pessoa. A legitimidade do ato de quebra do sigilo bancário, além de supor a plena adequação de tal medida ao que prescreve a Constituição, deriva da necessidade de a providência em causa respeitar, quanto à sua adoção e efetivação, o princípio da colegialidade, sob pena de essa deliberação reputar-se nula."

11 BRASIL. Supremo Tribunal Federal. Mandado de Segurança n 33.663, Rel. Min. Celso de Mello, publicado em 18 ago.2015: "Impossibilidade jurídica de CPI praticar atos sobre os quais incida a cláusula constitucional da reserva de jurisdição, como a busca e apreensão domiciliar (...). Possibilidade, contudo, de a CPI ordenar busca e apreensão de bens, objetos e computadores, desde que essa diligência não se efetive em local inviolável, como os espaços domiciliares, sob pena, em tal hipótese, de invalidade da diligência e de ineficácia probatória dos elementos informativos dela resultantes. Deliberação da CPI/Petrobras que, embora não abrangente do domicílio dos impetrantes, ressentir-se-ia da falta da necessária fundamentação substancial. Ausência de indicação, na espécie, de causa provável e de fatos concretos que, se presentes, autorizariam a medida excepcional da busca e apreensão, mesmo a de caráter não domiciliar." 
cogitar de que o argumento das questões "interna corporis" funcionaria como um óbice no particular, independentemente da interpretação de normas regimentais.

Como se vê, ao examinar questões relacionadas com o funcionamento interno das Casas Legislativas e com suas competências fiscalizatórias - particularmente envolvendo a atuação de CPIs -, o STF não considera a eventual interpretação de normas regimentais como o critério que define se lhe cabe ou não controlar o ato do Poder Legislativo. O mesmo acontece em relação às competências sancionadoras a cargo do Legislativo, seja quando elas se dirigem aos próprios parlamentares ou ao Chefe do Executivo em procedimentos por crime de responsabilidade. Com efeito, o STF em várias oportunidades tem considerado que lhe cabe examinar atos do Legislativo nesse contexto, embora eles envolvam a interpretação de normas regimentais. $\mathrm{O}$ argumento central é que, a despeito do espaço próprio das normas regimentais para regular tais procedimentos sancionadores, elas não podem violar determinados conteúdos que decorrem das garantias constitucionais do direito de defesa e do devido processo legal ${ }^{12}$. Assim, por exemplo, o STF considerou inválida, por violar o devido processo legal, a reinquirição de testemunhas de acusação ouvidas após as da defesa em processo por quebra de decoro parlamentar ${ }^{13}$. Também no âmbito de processos por crime de

12 V. BRASIL. Supremo Tribunal Federal. Mandado de Segurança n 34.327, Rel. Min. Luís Roberto Barroso, publicado em 01 ago. 2017: “Ementa: DIREITO CONSTITUCIONAL. MANDADO DE SEGURANÇA. CASSAÇÃO DE MANDATO DE DEPUTADO FEDERAL. QUEBRA DE DECORO PARLAMENTAR. ALEGADAS NULIDADES. 1. O Supremo Tribunal Federal somente deve interferir em procedimentos legislativos para assegurar o cumprimento da Constituição, proteger direitos fundamentais e resguardar os pressupostos de funcionamento da democracia e das instituições republicanas. Exemplo típico na jurisprudência é a preservação dos direitos das minorias. Nenhuma das hipóteses ocorre no presente caso. 2. A suspensão do exercício do mandato do impetrante, por decisão desta Corte em sede cautelar penal, não gera direito à suspensão do processo de cassação do mandato: ninguém pode se beneficiar da própria conduta reprovável. Inexistência de violação à ampla defesa ou de direito subjetivo a dilações indevidas. O precedente formado no MS 25.579 MC, Rel. p/ o acórdão Min. Joaquim Barbosa, se referia a parlamentar afastado para exercer cargo no Executivo e responsabilizado por atos lá praticados. Naquele caso, aliás, a medida liminar foi indeferida, pois se reputou a infração enquadrada no Código de Ética e Decoro Parlamentar. 3. A alegação de que o relator do processo no Conselho de Ética estaria impedido por integrar o mesmo bloco parlamentar do impetrante, por pressupor debate sobre o momento relevante para aferição da composição dos blocos, não configura hipótese justificadora de intervenção judicial. Precedente: MS 33.729 MC, de minha relatoria. 4. Não há que se falar em violação ao contraditório decorrente do aditamento da denúncia, providência admitida até em sede de processo penal, uma vez que o impetrante teve todas as possibilidades de se defender, o que foi feito de forma ampla e tecnicamente competente. 5. Ausência de ilicitude na adoção da votação nominal do parecer no Conselho de Ética, forma que mais privilegia a transparência e o debate parlamentar, e adotada até em hipóteses mais graves do que a ora em discussão. Deferência para com a interpretação regimental acolhida pelo órgão parlamentar, inclusive à vista das dificuldades para aplicação do art. 187, § 4 , do RI/CD fora do Plenário da Câmara dos Deputados. Inexistência de vedação expressa e inocorrência de "efeito manada". 6. Validade do quórum de instalação da sessão na Comissão de Constituição e Justiça. Não há nas Comissões suplentes vinculados.".

13 BRASIL. Supremo Tribunal Federal. Mandado de Segurança n 25.647, Rel. Min. Carlos Britto, publicado em 15 dez. 2006: “EMENTA: PARLAMENTAR. Perda de mandato. Processo de cassação. Quebra de decoro parlamentar. Inversão da ordem das provas. Reinquirição de testemunha de acusação ouvida após as da defesa. Indeferimento pelo Conselho de Ética. Inadmissibilidade. Prejuízo presumido. Nulidade conseqüente. Inobservância do contraditório e da ampla defesa. Vulneração do justo processo da lei (due process of law). Ofensa aos arts. $5^{\circ}$, incs. LIV e LV, e 55, § $2^{\circ}$, da CF. Liminar concedida em parte, pelo voto intermediário, para suprimir, do Relatório da Comissão, o inteiro teor do depoimento e das referências que lhe faça. Votos vencidos. Em 
responsabilidade contra o Chefe do Executivo, e por fundamentos similares, o STF fixou que o acusado tem o direito de se manifestar após a acusação ${ }^{14}$. Mas não são apenas direitos fundamentais vinculados ao direito de defesa e ao devido processo legal que fundamentam a atuação do STF no particular. A Corte invocou os princípios democrático, representativo e republicano, e as exigências de transparência e prestação de contas que deles decorre, para impor que todas as votações nos processos de impeachment sejam abertas, a despeito da interpretação interna das Casas acerca das normas regimentais aplicáveis ${ }^{15}$.

Por fim, cabe retornar ao processo legislativo, tema em torno do qual gira o recurso extraordinário que deu origem ao Tema 1.120 de repercussão geral. Será que nesse ambiente específico, ao contrário do que acontece nos outros contextos identificados acima, o critério da "interpretação de normas regimentais" seria efetivamente adotado pelo STF para decidir quando lhe cabe ou não examinar atos do Poder Legislativo? A resposta também aqui é negativa, embora em algumas hipóteses o critério até possa ser utilizado pela Corte para bloquear o conhecimento de postulações que Ihe são submetidas. Nada obstante, não se trata de um entendimento consolidado, ao contrário. Em diversos casos - e sobretudo quando a questão é levada à Corte por parlamentares - a circunstância de a hipótese envolver a interpretação de normas regimentais não impede que o STF conheça da questão. Alguns exemplos são capazes de demonstrar o ponto.

processo parlamentar de perda de mandato, não se admite aproveitamento de prova acusatória produzida após as provas de defesa, sem oportunidade de contradição real."

14 BRASIL. Supremo Tribunal Federal. Arguição de Descumprimento de Preceito Fundamental $\mathbf{n}^{\circ}$ 378/MC, Rel. Min. Luís Roberto Barroso, publicado em 8 mar. 2016: “A DEFESA TEM DIREITO DE SE MANIFESTAR APÓS A ACUSAÇÃO (ITEM E DO PEDIDO CAUTELAR): No curso do procedimento de impeachment, o acusado tem a prerrogativa de se manifestar, de um modo geral, após a acusação. Concretização da garantia constitucional do devido processo legal (due process of law). Precedente: MS 25.647-MC, Redator p/ acórdão Min. Cezar Peluso, Plenário. Procedência do pedido."

15 BRASIL. Supremo Tribunal Federal. Arguição de Descumprimento de Preceito Fundamental n $^{\circ}$ 378/MC, Rel. Min. Luís Roberto Barroso, publicado em 8 mar. 2016: “5. A VOTAÇÃO PARA FORMAÇÃO DA COMISSÃO ESPECIAL SOMENTE PODE SE DAR POR VOTO ABERTO (CAUTELAR INCIDENTAL): No impeachment, todas as votações devem ser abertas, de modo a permitir maior transparência, controle dos representantes e legitimação do processo. No silêncio da Constituição, da Lei n 1.079/1950 e do Regimento Interno sobre a forma de votação, não é admissível que o Presidente da Câmara dos Deputados possa, por decisão unipessoal e discricionária, estender hipótese inespecífica de votação secreta prevista no RI/CD, por analogia, à eleição para a Comissão Especial de impeachment. Em uma democracia, a regra é a publicidade das votações. O escrutínio secreto somente pode ter lugar em hipóteses excepcionais e especificamente previstas. Além disso, o sigilo do escrutínio é incompatível com a natureza e a gravidade do processo por crime de responsabilidade. Em processo de tamanha magnitude, que pode levar o Presidente a ser afastado e perder o mandato, é preciso garantir o maior grau de transparência e publicidade possível. Nesse caso, não se pode invocar como justificativa para o voto secreto a necessidade de garantir a liberdade e independência dos congressistas, afastando a possibilidade de ingerências indevidas. Se a votação secreta pode ser capaz de afastar determinadas pressões, ao mesmo tempo, ela enfraquece o controle popular sobre os representantes, em violação aos princípios democrático, representativo e republicano. Por fim, a votação aberta (simbólica) foi adotada para a composição da Comissão Especial no processo de impeachment de Collor, de modo que a manutenção do mesmo rito seguido em 1992 contribui para a segurança jurídica e a previsibilidade do procedimento. Procedência do pedido." 
Inicie-se com o MS 22.503, julgado em maio de $1996^{16}$. Alguns trabalhos doutrinários criticaram essa decisão do STF de forma específica exatamente por consagrar a doutrina das questões interna corporis ${ }^{17}$. De fato, isso foi afirmado pela Corte, mas a assertiva não corresponde ao que foi efetivamente decidido. O mandado de segurança foi impetrado por parlamentares contra ato do Presidente da Câmara dos Deputados que submeteu a discussão e votação da Casa emenda aglutinativa de emenda constitucional que, segundo os impetrantes, já havia sido rejeitada na mesma sessão legislativa. A impetração invoca como violados uma série de dispositivos regimentais, não fazendo menção, curiosamente, ao art. $60, \S 5^{\circ}$ da Constituição que traz previsão nesse mesmo sentido.

A Corte não conheceu do mandado de segurança relativamente aos fundamentos regimentais, entendendo que se trataria de matéria interna corporis. Reconhecendo, porém, que a mesma regra consta do art. $60, \S 5^{\circ}$ da Constituição, conheceu do writ sob esse fundamento, ainda que não tivesse sido invocado. Para decidir a questão, porém, a Corte não pode evitar de ocupar-se do exame das normas regimentais que definem o que deve ser considerado como proposta original, em que consistem substitutivos e

16 BRASIL. Supremo Tribunal Federal. Mandado de Segurança n 22.503, Rel. para o acórdão Min. Maurício Correa publicado em 6 jun. 2017:"I - Preliminar. 1. Impugnação de ato do Presidente da Câmara dos Deputados que submeteu a discussão e votação emenda aglutinativa, com alegação de que, além de ofender ao par. único do art. 43 e ao $\S 3^{\circ}$ do art. 118, estava prejudicada nos termos do inc. VI do art. 163, e que deveria ter sido declarada prejudicada, a teor do que dispõe o n. 1 do inc. I do art. 17, todos do Regimento Interno, lesando o direito dos impetrantes de terem assegurados os princípios da legalidade e moralidade durante o processo de elaboração legislativa. A alegação, contrariada pelas informações, de impedimento do relator - matéria de fato - e de que a emenda aglutinativa inova e aproveita matérias prejudicada e rejeitada, para reputá-la inadmissível de apreciação, é questão interna corporis do Poder Legislativo, não sujeita à reapreciação pelo Poder Judiciário. Mandado de segurança não conhecido nesta parte. 2. Entretanto, ainda que a inicial não se refira ao $\S 5^{\circ}$ do art. 60 da Constituição, ela menciona dispositivo regimental com a mesma regra; assim interpretada, chega-se à conclusão que nela há ínsita uma questão constitucional, esta sim, sujeita ao controle jurisdicional. Mandado de segurança conhecido quanto à alegação de impossibilidade de matéria constante de proposta de emenda rejeitada ou havida por prejudicada poder ser objeto de nova proposta na mesma sessão legislativa. II - Mérito. 1. Não ocorre contrariedade ao $\S 5^{\circ}$ do art. 60 da Constituição na medida em que o Presidente da Câmara dos Deputados, autoridade coatora, aplica dispositivo regimental adequado e declara prejudicada a proposição que tiver substitutivo aprovado, e não rejeitado, ressalvados os destaques (art. 163, V). 2. É de ver-se, pois, que tendo a Câmara dos Deputados apenas rejeitado o substitutivo, e não o projeto que veio por mensagem do Poder Executivo, não se cuida de aplicar a norma do art. $60, \S 5 \circ$, da Constituição. Por isso mesmo, afastada a rejeição do substitutivo, nada impede que se prossiga na votação do projeto originário. $O$ que não pode ser votado na mesma sessão legislativa é a emenda rejeitada ou havida por prejudicada, e não o substitutivo que é uma subespécie do projeto originariamente proposto. 3. Mandado de segurança conhecido em parte, e nesta parte indeferido.".

17 V., por exemplo, SILVA, Adriana Campos; SOUZA, Rafael Costa de. O Supremo Tribunal Federal e o processo legislativo constitucional: análise crítica da postura passivista procedimental adotada no julgamento do Mandado de Segurança n 22.503-3/DF. Revista da Faculdade de Direito da UFRGS, Porto Alegre, n. 36, pp. 146-163, ago. 2017. Disponível em: <https://seer.ufrgs.br/revfacdir/article/view/73148>. Acesso em 1 abr. 2021; BUSTAMANTE, Thomas e BUSTAMANTE, Evanilda de Godoi. Jurisdição Constitucional na Era Cunha: entre o Passivismo Procedimental e o Ativismo Substancialista do STF. Revista Direito \& Praxis, Rio de Janeiro, vol. 7, n. 13, pp. 346-388, 2016. Disponível em <https://www.e-publicacoes.uerj.br/index.php/revistaceaju/article/ view/17530>. Acesso em 1 abr. 2021. 
emendas aglutinativas, bem como o que se considera como matérias rejeitadas ou prejudicadas. A conclusão do STF - em clara interpretação das normas regimentais (correta ou incorreta, não se ingressa aqui na discussão de fundo) - foi a de que o Presidente do Senado havia aplicado adequadamente as normas regimentais na hipótese já que apenas o substitutivo à PEC havia sido rejeitado, e não a proposta original encaminhada pelo Executivo, de modo que o dispositivo constitucional não se aplicaria. O MS foi afinal conhecido, em parte, e indeferido.

Saltando para maio de 2006, vale examinar agora a ADI 3.146, na qual se questionava a inconstitucionalidade formal de dispositivo da Lei $n^{\circ} 10.828 / 03^{18}$. A hipótese era basicamente a seguinte. A secretaria do Senado Federal havia recebido, vindas da Câmara, duas medidas provisórias dois dias antes da deliberação do projeto de lei (PL) que deu origem à lei impugnada. As MPs, entretanto, ainda não tinham sido lidas no Plenário, de modo que o Presidente do Senado entendeu que, ausente a leitura, não se produzia o efeito de sobrestamento das demais proposições legislativas previsto pela Constituição, e o PL foi alvo de deliberação. As MPs acabaram sendo lidas e votadas na mesma sessão, apenas que após o PL. O partido requerente da ADI considerava que o fundamento da decisão do Presidente do Senado - de que a "ausência de leitura" da MP impedia o efeito de bloqueio da pauta - autorizaria uma fraude à Constituição, já que bastaria ao Senado "reter" as MPs e não proceder à sua leitura para impedir a incidência do dispositivo constitucional.

Quando do julgamento da ADI 3.146, vários Ministros registraram que a questão envolvia a interpretação de normas regimentais, apesar do possível impacto que eventual abuso por parte do Legislativo no uso do argumento da "ausência de leitura" das MPs poderia gerar sobre o art. $62, \S 6^{\circ}$ da Constituição, abuso que a Corte entendeu, entretanto, não ter ocorrido no caso examinado. O Ministro Carlos Britto chegou a afirmar: "Entendo que nesse momento, não devemos caracterizar o tema, se é matéria, ou não, interna corporis. Essa linha divisória, aqui, está muito imprecisa, muito tênue... Ao fim, o STF, por maioria, conheceu da ação e a julgou improcedente, por não visualizar abuso ou fraude na hipótese. A maioria dos Ministros sinalizou, porém, que diante de outras circunstâncias, em que observado abuso, o entendimento seria diverso, no sentido da inconstitucionalidade formal.

Mais um salto no tempo, agora para outubro de 2015. Ao julgar a ADI 5.127 ${ }^{19}$ o STF, por maioria, firmou o entendimento no sentido da inconstitucionalidade formal de emendas a projetos de conversão de medidas provisórias que não guardem pertinência temática com o conteúdo original da MP, os chamados "contrabandos legislativos",

18 BRASIL. Supremo Tribunal Federal. Ação Direta de Inconstitucionalidade no 3.146, Rel. Min. Joaquim Barbosa, publicado em 19 dez. 2006.

19 BRASIL. Supremo Tribunal Federal. Ação Direta de Inconstitucionalidade n 5.127, Rel. para o acordão Min. Edson Fachin, publicado em 11 mai. 2016. 
a ser aplicado apenas para o futuro. Não há norma específica na Constituição que trate do assunto, e o ponto foi expressamente reconhecido inclusive pelos Ministros que formaram a maioria. Interessantemente, um dos argumentos suscitados, tanto pela corrente vencedora, quanto pela vencida, foi a existência de norma regimental sobre o ponto: a Resolução 1/2002 do Congresso Nacional, que integra o Regimento Comum. A norma expressamente veda o "contrabando legislativo", atribuindo ao Presidente da Comissão Mista a competência para o indeferimento liminar de emendas que versem sobre matéria estranha ao tratado na medida provisória e regulando a possibilidade de recurso dessa decisão a ser decidido pelo plenário da Comissão ${ }^{20}$.

Para o Ministro Dias Toffoli, que restou vencido, exatamente por não haver norma constitucional expressa e a questão ser tratada em norma regimental "não cabe a este Supremo Tribunal avaliar se determinado ato normativo, resultante de emenda a projeto de conversão de medida provisória, veicula matéria correlata ou não ao tema do ato normativo originário. Essa questão diz respeito a assunto interno do Poder Legislativo, não devendo ser sindicada pelo Poder Judiciário.". Para o Ministro Luís Roberto Barroso, por seu turno, que integrou a maioria, de fato não há norma constitucional expressa sobre a matéria e desenvolveu-se ao longo do tempo, no âmbito do Legislativo, um costume constitucional que admitia o "contrabando legislativo"; mais recentemente, porém, passou-se a perceber que esse costume é incompatível com a Constituição ${ }^{21}$.

20 Resolução 1/2020, do Congresso Nacional: "Art. 4 Nos 6 (seis) primeiros dias que se seguirem à publicação da Medida Provisória no Diário Oficial da União, poderão a ela ser oferecidas emendas, que deverão ser protocolizadas na Secretaria-Geral da Mesa do Senado Federal. § $1^{\circ}$ Somente poderão ser oferecidas emendas às Medidas Provisórias perante a Comissão Mista, na forma deste artigo. $\S 2^{\circ}$ No prazo de oferecimento de emendas, o autor de projeto sob exame de qualquer das Casas do Congresso Nacional poderá solicitar à Comissão que ele tramite, sob a forma de emenda, em conjunto com a Medida Provisória. $\S 3^{\circ} \mathrm{O}$ projeto que, nos termos do $\S 2^{\circ}$, tramitar na forma de emenda à Medida Provisória, ao final da apreciação desta, será declarado prejudicado e arquivado, exceto se a Medida Provisória for rejeitada por ser inconstitucional, hipótese em que o projeto retornará ao seu curso normal. § $4^{\circ}$ É vedada a apresentação de emendas que versem sobre matéria estranha àquela tratada na Medida Provisória, cabendo ao Presidente da Comissão o seu indeferimento liminar. $\S 5^{\circ} \mathrm{O}$ autor da emenda não aceita poderá recorrer, com o apoio de 3 (três) membros da Comissão, da decisão da Presidência para o Plenário desta, que decidirá, definitivamente, por maioria simples, sem discussão ou encaminhamento de votação. $§ 6^{\circ}$ Os trabalhos da Comissão Mista serão iniciados com a presença, no mínimo, de 1/3 (um terço) dos membros de cada uma das Casas, aferida mediante assinatura no livro de presenças, e as deliberações serão tomadas por maioria de votos, presente a maioria absoluta dos membros de cada uma das Casas."

21 BRASIL. Supremo Tribunal Federal. Ação Direta de Inconstitucionalidade $\mathbf{n}^{\circ}$ 5.127, Rel. para o acordão Min. Edson Fachin, publicado em 11 mai. 2016, trecho do voto do Ministro Luís Roberto Barroso: "A questão, basicamente, é a seguinte: não existe uma regra na Constituição que proíba expressamente a apresentação de emendas parlamentares às medidas provisórias que não tenham pertinência temática. Simplesmente não existe essa regra, nem essa previsão. Diante da ausência de proibição, pelo menos explícita, o que se desenvolveu, Presidente e Ministro Celso de Mello, foi um costume que admitia essa prática. Um costume, como sabemos, é uma importante fonte subsidiária do Direito. O costume consiste, basicamente, numa prática reiterada que seja socialmente aceita. E, portanto, parece-me fora de dúvida que estamos falando de um costume constitucional que se criou e que se consolidou ao longo dos muitos anos de vigência da Constituição de 1988. (...) mais recentemente, adveio uma clara percepção de que esse costume é incompatível com a Constituição. Esse é um costume que produz efeitos colaterais graves e antagônicos à Constituição, como apontou a Ministra Rosa Weber no seu voto." 
Como se percebe, e salvo para o Ministro Dias Toffoli, a questão de a matéria envolver, como envolvia, normas regimentais não representou óbice a que a Corte conhecesse do assunto e decidisse acerca dele. Do ponto de vista constitucional, como os votos e a ementa apontam, a racionalidade adotada pelo STF para concluir pela inconstitucionalidade da prática decorre dos impactos negativos que o contrabando legislativo produz sobre os princípios democrático e o devido processo legislativo, tendo em conta, dentre outros argumentos, a enorme limitação para o debate parlamentar e social que esse artifício gera, fraudando a dinâmica natural do processo legislativo ordinário. Assim, não parece consistente afirmar, também em relação ao processo legislativo, que a circunstância de o tema envolver a interpretação de normas regimentais impediria seu conhecimento pelo Judiciário por atrair a cláusula das questões "interna corporis".

Por fim, no MS 27.931, em julgamento realizado em junho de 2017, o Plenário do STF confirmou entendimento do Relator, Ministro Celso de Mello, proferido em 2009, que indeferiu mandado de segurança impetrado por parlamentares contra deliberação do Presidente da Câmara dos Deputados. A controvérsia no âmbito da Câmara envolvia a extensão do trancamento da pauta produzido por medidas provisórias não deliberadas no prazo constitucional e, nesse contexto, se discutia o sentido da expressão "todas as demais deliberações legislativas da Casa em que estiver tramitando", contida no art. $62, \S 6^{\circ}$ da Constituição de 1988. O Presidente da Casa, em resposta a questão de ordem, decidiu que a expressão constitucional abarcaria apenas as deliberações que versassem sobre matérias que pudessem ser disciplinadas por meio de medida provisória. As demais deliberações, portanto, não sofreriam o efeito de trancamento da pauta. Inconformados com esse entendimento, a seu ver incompatível com o texto constitucional, parlamentares impetraram o referido mandado de segurança.

Curiosamente, tanto o Relator, quanto o colegiado, indeferiram o mandado de segurança - mantendo a validade da decisão do Presidente da Câmara dos Deputados - mas não por se tratar de questão interna corporis, já que envolveria a interpretação de normas internas. A Corte não se limitou a produzir o efeito prático de manter a decisão do Presidente da Casa Legislativa, o que seria alcançado pela denegação da ordem, sob o fundamento de autocontenção por conta da separação de poderes. Muito ao contrário, o STF indeferiu o mandado de segurança e deu interpretação conforme ao art. 62 , § $6^{\circ}$ da Constituição de 1988 para definir - com clara pretensão de que tal entendimento seja aplicado de forma geral - que o sentido do texto constitucional seja aquele definido pelo Presidente da Câmara dos Deputados, e não qualquer outro. Ou seja: a norma interna da Casa Legislativa (de seu Presidente, a rigor) foi utilizada para dar interpretação conforme ao texto constitucional. Esse o dispositivo da decisão: 
"O Tribunal, por maioria e nos termos do voto do Ministro Celso de Mello (Relator), indeferiu o mandado de segurança e deu, ao § $6^{\circ}$ do art. 62 da Constituição, na redação resultante da EC 32/2001, interpretação conforme à Constituição, para, sem redução de texto, restringir-Ihe a exegese, em ordem a que, afastada qualquer outra possibilidade interpretativa, seja fixado entendimento de que o regime de urgência previsto em tal dispositivo constitucional - que impõe o sobrestamento das deliberações legislativas das Casas do Congresso Nacional - refere-se, tão somente, àquelas matérias que se mostram passíveis de regramento por medida provisória, excluídos, em consequência, do bloqueio imposto pelo mencionado $\S 6^{\circ}$ do art. 62 da Lei Fundamental, as propostas de emenda à Constituição e os projetos de lei complementar, de decreto legislativo, de resolução e, até mesmo, tratando-se de projetos de lei ordinária, aqueles que veiculem temas pré-excluídos do âmbito de incidência das medidas provisórias (CF, art. 62, § 10, I, II e IV)."22

As razões que levaram a tal decisão por parte do STF se relacionam com o que a Corte percebia como um abuso no uso de medidas provisórias bloqueando a pauta do Legislativo e impedindo o desenvolvimento das funções institucionais do Congresso Nacional. A solução concebida pelo Presidente da Câmara dos Deputados foi visualizada como uma forma de minimizar esse problema, devendo não só ser preservada, mas adotada como interpretação conforme da própria Constituição. Para a maioria, a despeito de se tratar de uma norma interna do Legislativo, a questão envolvia, na expressão do Relator, um "litígio constitucional", afetando o equilíbrio e o controle recíproco entre os Poderes Legislativo e Executivo ${ }^{23}$. A decisão menciona ainda um direito público subjetivo dos parlamentares à correta elaboração das leis e demais atos normativos, que estaria sendo prejudicado pelo bloqueio do funcionamento legislativo normal em função da quantidade de medidas provisórias. Também aqui, como se vê, a circunstância de a interpretação do caso envolver normas internas da Câmara dos Deputados não impediu, muito ao revés, que o STF conhecesse da controvérsia.

22 BRASIL. Supremo Tribunal Federal. Mandado de Segurança n 27.931, Rel. Min. Celso de Mello, publicado em 28 out. 2020 .

23 Trecho do voto do Ministro Relator: "2. Possibilidade de controle jurisdicional da deliberação parlamentar ora questionada, por ocorrente, na espécie, situação configuradora de litígio constitucional. (...) Em uma palavra, Senhor Presidente: a índole política dos atos e procedimentos parlamentares não basta, só por si, para subtraí-los à esfera de controle jurisdicional, eis que sempre caberá, a esta Suprema Corte, mediante formal provocação da parte lesada, o exercício da jurisdição constitucional - que lhe é inerente -, nos casos em que se alegue ofensa, atual ou iminente, a direitos individuais ou a cláusulas constitucionais em geral, pois nenhum Poder da República tem legitimidade para desrespeitar a Constituição ou para ferir direitos públicos e privados de seus cidadãos ou de membros integrantes de qualquer dos Poderes do Estado. (...) 3. A competência extraordinária de editar medidas provisórias não pode legitimar práticas de cesarismo governamental nem inibir o exercício, pelo Congresso Nacional, de sua função primária de legislar." (...) Entendo, por isso mesmo, Senhor Presidente, considerada a "ratio " subjacente à decisão ora impugnada, que a solução interpretativa dada pelo Senhor Presidente da Câmara dos Deputados encerra uma resposta jurídica qualitativamente superior àquelas que buscam sustentar - e, mais grave, preservar - virtual interdição das funções legislativas do Congresso Nacional. 
A seleção de casos apresentada acima, e sem prejuízo de uma pesquisa ainda mais abrangente, permite concluir com conforto que não é correta a afirmação de que a jurisprudência predominante do STF qualifica como questões interna corporis - para o fim de concluir que não lhe cabe conhecer da matéria - casos que envolvam a interpretação de normas regimentais ou, de forma mais geral, normas internas das Casas Legislativas. Embora alguns casos sejam solucionados dessa forma e a assertiva teórica seja utilizada pela Corte, diversos outros casos, de grande repercussão inclusive, não utilizam essa espécie de critério decisório.

\section{COM BASE EM QUAIS FUNDAMENTOS AFINAL O STF CONTRO- LA ATOS DO PODER LEGISLATIVO? UMA TENTATIVA PRELIMI- NAR DE SISTEMATIZAÇÃO E CRÍTICA}

Se o critério adotado pelo STF para definir o que são ou não questões "interna corporis" não é necessariamente, como se viu, a interpretação de norma regimental, que critérios o STF utiliza afinal? Que fundamentos definem ou ao menos delineiam as hipóteses em que o Judiciário pode ou não rever atos do Poder Legislativo? Já se discutiu inicialmente a importância de que tais fundamentos sejam claros, consistentes e previsíveis.

Uma primeira conclusão que se pode apurar da jurisprudência examinada revela que o STF tende a utilizar como critério para avaliar se lhe cabe ou não rever atos do Legislativo o impacto que tais atos tenham ou possam ter sobre alguma norma constitucional, explícita ou implícita; muito mais do que a necessidade ou não de que normas regimentais sejam interpretadas e aplicadas para solução do caso. Dito de outro modo, o possível impacto sobre normas constitucionais é um argumento capaz de derrotar com relativa facilidade aquele outro da interpretação das normas regimentais. Naturalmente que "possível impacto sobre normas constitucionais explícitas ou implícitas" não chega a ser um critério minimamente claro ou previsível, sobretudo tendo em conta a abrangência da Constituição de 1988. Mas é possível avançar.

A partir dos casos narrados acima, é possível identificar desde logo três grupos de normas constitucionais que desencadearam o controle do STF sobre atos do Poder Legislativo e, portanto, sinalizam parâmetros na matéria. Algumas dessas normas se apresentam de forma razoavelmente clara e previsível e, portanto, são capazes de comunicar aos Legislativos que essas são previsões que, se desrespeitadas, autorizarão controle judicial. O mesmo não se pode dizer em relação a outras, de modo que será da maior importância, para os fins discutidos inicialmente, que a doutrina e a própria jurisprudência do STF ao longo do tempo sejam capazes de conferir maior clareza, consistência e previsibilidade a esses parâmetros. 
O primeiro grupo de normas constitucionais que mobilizam o controle judicial de atos do Legislativo são direitos individuais. O STF entende - com toda razão - que o Legislativo, como qualquer órgão estatal, deve respeito aos direitos individuais assegurados pela Constituição de 1988, como o direito de ir e vir, o direito ao contraditório e a ampla defesa, o direito à privacidade e a eventuais sigilos que ele autorize, bem como à proteção de dados e do domicílio, dentre outros. Assim, seja na organização interna das Casas Legislativas, seja na sua atuação de fiscalização ou de aplicação de sanções, tais direitos individuais previstos pela Constituição têm sido considerados fundamentos válidos para a intervenção judicial na atividade do Poder legislativo, ainda que para tanto seja necessário examinar, interpretar ou mesmo invalidar norma interna das Casas Legislativas.

Um segundo grupo de normas constitucionais reúne previsões que a Corte tem identificado como prerrogativas dos próprios parlamentares e sobretudo das minorias parlamentares. Outras decisões do STF, além das discutidas aqui sobre o direito das minorias à instauração de CPIs, poderiam ser incluida aqui, como aquelas que autorizam os parlamentares a impetrar mandado de segurança contra processo legislativo que vise à deliberação de proposição tendente a abolir cláusula pétrea. Tais decisões não foram examinadas aqui pois não se relacionam diretamente com o tema das questões "interna corporis".

Um terceiro grupo de normas diz respeito à separação de poderes e à preservação do Legislativo - de seu funcionamento adequado e de suas funções - em face do Executivo. O exemplo aqui é a decisão proferida no MS 27.931, que consagrou o entendimento firmado pelo Presidente da Câmara acerca das matérias que sofreriam o efeito obstativo das medidas provisórias. De toda sorte, não é irrelevante observar que o STF entendeu que poderia intervir em uma disputa interna entre os próprios parlamentares sob o fundamento de preservar a separação de poderes e os controles recíprocos que ela exige, reconhecendo o impacto que a dinâmica do presidencialismo brasileiro e das relações entre maioria e minoria parlamentar têm sobre esses elementos constitucionais.

Por fim, um quarto grupo de normas constitucionais congrega as previsões da Constituição de 1988 acerca do processo legislativo em suas conexões com o devido processo legislativo, com a democracia, com a cidadania, com a necessidade de transparência e prestação de contas e com a garantia de condições para que o controle e participação sociais sejam levadas a cabo nesse contexto. Diferentemente do segundo grupo referido acima, aqui o STF visualiza um direito difuso da sociedade a que tais elementos constitucionais sejam respeitados, e não apenas dos parlamentares.

As decisões do STF que tratam de violações diretas a normas constitucionais sobre o processo legislativo não foram examinadas aqui pois não demonstrariam o ponto objeto deste estudo. Os casos selecionados veiculam exemplos nos quais a Corte 
entendeu que, a despeito da ausência de normas constitucionais expressas, os atos do Legislativo teriam o potencial de fraudar ou estariam de fato fraudando o processo legislativo constitucional de alguma forma, ou tendo impacto negativo sobre a dinâmica democrática de forma mais geral. O STF parece afinal reconhecer - como a doutrina tem destacado ${ }^{24}$ - que em muitos contextos há uma inevitável imbricação entre o processo legislativo constitucional e normas internas das Casas Legislativas que detalham afinal esse percurso da elaboração das leis.

Esse talvez seja o grupo de normas constitucionais que, ao menos por enquanto, ainda não recebeu um tratamento mais claro e sistemático da jurisprudência do STF, e que demanda maior discussão e aprofundamento doutrinário e jurisprudencial. Há, como se sabe, ampla crítica ao Poder Judiciário quando ele avança sobre o mérito das leis, por vezes sobre temas socialmente sensíveis, para considerar inválido aquilo que foi decidido pelas instâncias majoritárias e pelo Legislativo em particular. A situação será diversa, porém, no caso da intervenção judicial que visa a contribuir - como no caso desse quarto conjunto de normas referido - para o reforço procedimental do processo legislativo e para a melhoria das condições da deliberação democrático-majoritária a ser levada a cabo pelos representantes eleitos pela população 25 .

\section{CONCLUSÃO}

O que se apurou neste trabalho é que a "interpretação das normas regimentais das Casas Legislativas" não é o critério adotado de forma consistente pela jurisprudência do STF para identificar questões "interna corporis" que, por isso, estariam fora de seu controle. Em diferentes contextos, inclusive e particularmente no âmbito do processo legislativo, apesar de não haver norma constitucional expressa, a Corte decide controlar atos do Legislativo por entender que eles, a despeito de envolverem a interpretação e

24 DEL NEGRI, Andre冈. Processo constitucional e decisão interna corporis. Belo Horizonte: Fórum, 2011; e MACEDO, Cristiane Branco. A legitimidade e a extensão do controle judicial sobre o processo legislativo no Estado democrático de direito. Brasília, 2007. 235 f. Dissertação (Mestrado em Direito) - Faculdade de Direito, Universidade de Brasília. Disponível em <http://www2.senado.leg.br/bdsf/handle/id/178422>. Acesso em 1 abr. 2021.

25 OLIVEIRA, Marcelo Andrade Cattoni de. Devido processo legislativo: uma justificação democrática do controle jursidicional de constitucionalidade das leis e do processo legislativo. Belo Horizonte: Mandamentos, 2006; BARBOSA, Leonardo Augusto de Andrade. Processo legislativo e democracia. Belo Horizonte: Del Rey, 2010; BARCELLOS, Ana Paula de. Direitos Fundamentais e Direito à Justificativa. Devido Procedimento na Elaboração Normativa. 3.ed. Belo Horizonte: Fórum, 2020; BUSTAMANTE, Thomas e BUSTAMANTE, Evanilda de Godoi. Jurisdição Constitucional na Era Cunha: entre o Passivismo Procedimental e o Ativismo Substancialista do STF. Revista Direito \& Praxis, Rio de Janeiro, vol. 7, n. 13, pp. 346-388, 2016. Disponível em <https:// www.e-publicacoes.uerj.br/index.php/revistaceaju/article/view/17530>. Acesso em 1 abr. 2021; SCHIER, Paulo Ricardo. Armadilhas no devido processo legislativo em contextos democráticos. Revista de Direito Público Contemporâneo, a. 2, v. 1, n. 2, p. 60-7, jan./jun. 2017; e SALGADO, Eneida Desiree; ARAÚJO, Eduardo Borges Espínola. Controle judicial do processo legislativo. Do minimalismo à garantia do devido procedimento legislativo. Revista de Informação Legislativa, Brasília, a. 56, n. 224, p. 79-104, out./dez. 2019. 
aplicação de normas regimentais, repercutem sobre fins constitucionais considerados relevantes em cada caso. $O$ critério da interpretação e aplicação de normas regimentais é, portanto, pouco útil para oferecer parâmetros claros, consistentes e previsíveis que possam balizar a atuação do próprio STF, dos demais órgãos do Poder Judiciário e dos Legislativos brasileiros.

Nos casos examinados a Corte decidiu controlar atos do Poder Legislativo, a despeito da questão regimental, para proteger elementos constitucionais que considerou relevantes, dentre os quais a proteção de direitos individuais, a proteção de prerrogativas das minorias parlamentares, a autonomia do próprio Legislativo e a separação de poderes, e o devido processo legislativo, de modo a garantir transparência, prestação de contas e fomentar o debate e o controle públicos acerca das questões a serem decididas pelo Legislativo. Um tema importante para a doutrina e para a jurisprudência do STF nos próximos anos será a identificação mais precisa das dimensões dos fundamentos constitucionais que autorizam tal controle, de modo que, de um lado, seja possível ter maior clareza, consistência e previsibilidade acerca dos limites e possibilidades do controle judicial sobre os atos do Poder Legislativo e, de outro, a intervenção judicial possa contribuir de forma mais relevante para a melhoria das condições da deliberação democrático-majoritária no âmbito dos Legislativos.

\section{REFERÊNCIAS}

BARBOSA, Leonardo Augusto de Andrade. Processo legislativo e democracia. Belo Horizonte: Del Rey, 2010.

BARCELLOS, Ana Paula de. Direitos Fundamentais e Direito à Justificativa. Devido Procedimento na Elaboração Normativa. 3.ed. Belo Horizonte: Fórum, 2020.

BEDRITICHUK, R. R. Medida Provisória, uma moeda inflacionada: A inclusão das comissões no rito de tramitação das medidas provisórias e o aumento dos custos de aprovação. Brasília, 2015. 59 f. Monografia (especialização). Disponível em: <https://www2.senado.leg.br/bdsf/bitstream/ handle/id/516859/TCC_Rodrigo\%20Ribeiro\%20Bedritichuk.pdf?sequence=1\&isAllowed=y >.

BRASIL. Supremo Tribunal Federal. Ação Direta de Inconstitucionalidade n 5.127, Rel. para o acordão Min. Edson Fachin, publicado em 11 mai. 2016.

BRASIL. Supremo Tribunal Federal. Ação Direta de Inconstitucionalidade n 3.146, Rel. Min. Joaquim Barbosa, publicado em 19 dez. 2006.

BRASIL. Supremo Tribunal Federal. Arguição de Descumprimento de Preceito Fundamental nº 378/MC, Rel. Min. Luís Roberto Barroso, publicado em 8 mar. 2016.

BRASIL. Supremo Tribunal Federal. Mandado de Segurança n² 22.503, Rel. para o acórdão Min. Maurício Correa publicado em 6 jun. 2017. 


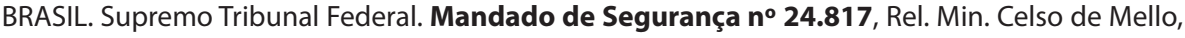
publicado em 6 nov. 2009.

BRASIL. Supremo Tribunal Federal. Mandado de Segurança n² 24.831, Rel. Min. Celso de Mello, publicado em 04 ago. 2006.

BRASIL. Supremo Tribunal Federal. Mandado de Segurança no 25.647, Rel. Min. Carlos Britto, publicado em 15 dez. 2006.

BRASIL. Supremo Tribunal Federal. Mandado de Segurança $\mathbf{n}^{\circ}$ 27.931, Rel. Min. Celso de Mello, publicado em 28 out.2020.

BRASIL. Supremo Tribunal Federal. Mandado de Segurança n 33.663, Rel. Min. Celso de Mello, publicado em 18 ago.2015.

BRASIL. Supremo Tribunal Federal. Mandado de Segurança n 34.327, Rel. Min. Luís Roberto Barroso, publicado em 01 ago. 2017.

BRASIL. Supremo Tribunal Federal., Habeas Corpus n 100.200, Rel. Min. Joaquim Barbosa, publicado em 27 ago. 2010.

BUSTAMANTE, Thomas e BUSTAMANTE, Evanilda de Godoi. Jurisdição Constitucional na Era Cunha: entre o Passivismo Procedimental e o Ativismo Substancialista do STF. Revista Direito \& Praxis, Rio de Janeiro, vol. 7, n. 13, pp. 346-388, 2016. Disponível em <https://www.e-publicacoes. uerj.br/index.php/revistaceaju/article/view/17530>. Acesso em 1 abr. 2021.

DEL NEGRI, André. Processo constitucional e decisão interna corporis. Belo Horizonte: Fórum, 2011.

LAAN, Cesar Rodrigues Van Der. Um panorama recente da apresentação de emendas sem pertinência temática a medidas provisórias pós-ADI 5.127. Brasília: Núcleo de Estudos e Pesquisas, CONLEG/Senado, Fevereiro/2018 (Texto para Discussão n 244). Disponível em <https://www12. senado.leg.br/publicacoes/estudos-legislativos/tipos-de-estudos/textos-para-discussao/td244>.

LIMA, Flávia Danielle Santiago; GOMES NETO, José Mário Wanderley. Autocontenção à brasileira? Uma taxonomia dos argumentos jurídicos (e estratégias políticas?) explicativo(a)s do comportamento do STF nas relações com os poderes majoritários. Revista de Investigações Constitucionais, Curitiba, vol. 5, n. 1, p. 221-247, jan./abr. 2018.

MACEDO, Cristiane Branco. A legitimidade e a extensão do controle judicial sobre o processo legislativo no Estado democrático de direito. Brasília, 2007. 235 f. Dissertação (Mestrado em Direito) - Faculdade de Direito, Universidade de Brasília. Disponível em <http://www2.senado.leg. br/bdsf/handle/id/178422>. Acesso em 1 abr. 2021.

OLIVEIRA, Marcelo Andrade Cattoni de. Devido processo legislativo: uma justificação democrática do controle jursidicional de constitucionalidade das leis e do processo legislativo. Belo Horizonte: Mandamentos, 2006. 
PEREIRA, Thomas, ALMEIDA, Guilherme da Franca Couto Fernandes de, e ARGUELHES, Diego Werneck. VIII Relatório Supremo em Números: Quem decide no Supremo. Rio de Janeiro: Editora FGV Rio, 2020.

SALGADO, Eneida Desiree; ARAÚJO, Eduardo Borges Espínola. Controle judicial do processo legislativo. Do minimalismo à garantia do devido procedimento legislativo. Revista de Informação Legislativa, Brasília, a. 56, n. 224, p. 79-104, out./dez. 2019.

SCHIER, Paulo Ricardo. Armadilhas no devido processo legislativo em contextos democráticos. Revista de Direito Público Contemporâneo, a. 2, v. 1, n. 2, p. 60-7, jan./jun. 2017.

SILVA, Adriana Campos; SOUZA, Rafael Costa de. O Supremo Tribunal Federal e o processo legislativo constitucional: análise crítica da postura passivista procedimental adotada no julgamento do Mandado de Segurança n 22.503-3/DF. Revista da Faculdade de Direito da UFRGS, Porto Alegre, n. 36, pp. 146-163, ago. 2017. Disponível em: <https://seer.ufrgs.br/revfacdir/article/ view/73148>. Acesso em 1 abr. 2021. 